\title{
The Companion Effect: Household and Local Context and the Turnout of Young People
}

\author{
Edward Fieldhouse University of Manchester \\ David Cutts University of Manchester
}

\begin{abstract}
Models of youth turnout often neglect the importance of the household and local context. Drawing on theories of socialization, contextual effects, and voting as habit, we offer an account of why some young people vote and others do not. Using evidence based on electoral returns from the 2001 British General Election, we find that young people's participation is particularly sensitive to the presence of other voters in the household. Using survey data, we discount the possibility that the effect is simply attributable to varying levels of political interest and strength of partisan support between households.
\end{abstract}

W hile electoral turnout is in decline in most western democracies (Blais 2006; Franklin 2004), it has been widely observed that the wane in electoral participation has been particularly acute among young voters (Blais 2000; Dalton 2008; Franklin 1996; Topf 1995; Wattenberg 2002). Although between 2004 and 2008 turnout for electors aged 18-29 increased in the U.S. presidential elections, the rate of participation was still more than 10 percentage points lower than the overall voter eligible turnout rate. It has been argued that a major factor contributing to the overall decline in turnout is the replacement of cohorts of older voters, socialized in times of high turnout, with new cohorts who have a lower propensity to vote (Franklin 2004). A crucial part of this argument is the role of habit. If voting is a habit, then the initial engagement of first-time voters in the electoral process will resonate throughout those voters' lives (Franklin 2004). While older voters who have already acquired their habits may be resistant to ephemeral influences, first-time voters who have not yet acquired the habit of voting may be impressionable and therefore more sensitive to the prevailing electoral context.

Another significant body of research has shown that both the household and the neighborhood are sources of contextual influences on voting (Cutts and Fieldhouse 2009; Johnston et al. 2005; Zuckerman 2005). Contextual voting theories hold that people follow similar patterns of political behavior when they live in close proximity, interact, share day-to-day experiences, and belong to the same social networks (Agnew 1987; Books and Prysby 1991; Cox 1969; Huckfeldt and Sprague 1995; Pattie and Johnston 2000). While many such studies focus on neighborhood effects, other studies have shown that the most important context of all-where political discussions and decisions occur-is the household (Cutts and Fieldhouse 2009; Johnston et al. 2005; Zuckerman 2005).

In this article, we contend that at particular points in their life-cycle, electors may be more or less prone to these contextual influences on turnout. The household effect may be most pronounced where electors are living in a family group (e.g., with spouses, offspring, or parents). An important mechanism that lies behind this is the tendency of electors to vote together (the "companion effect"). Moreover, we expect that firsttime voters-who have not yet acquired the habit of voting - will be the most susceptible to the influence of other household members, especially when they live in a family home.

Theories of voting often neglect the importance of the household, local, and political contexts which may be crucial in understanding whether first-time voters set off down the path of voting or of abstention. Adopting a contextual approach and expectations derived from theories of political socialization and voting as habit, we generate a number of hypotheses concerning the behavior of first-time voters. We employ 
evidence from a random sample of marked electoral registers at the 2001 British General Election to test these hypotheses on a cohort of young people that is eligible to vote for the first time in an election in $2001 .^{1}$ We find that young people's participation is affected by the presence (or absence) of other voters in the household to a greater degree than the electorate as a whole. Using survey data, we discount the possibility that this effect is solely attributable to characteristics of individuals and households, including educational attainment and varying levels of political interest, strength of partisan support, and political efficacy. We infer that the most plausible explanation of this is a "companion effect" whereby young people are especially influenced by whether there is another elector in the household with whom to visit the polling station. This inference is supported by new survey evidence concerning family/group voting.

\section{Theory}

Numerous theories for age and generational differentials have been put forward. For example, it has been argued that young voters are less engaged in politics in general because they are less integrated into society (Butler and Stokes 1974; Franklin 2004) and are less likely to have developed a strong party identification (Campbell et al. 1960). As individuals grow older and their stake in society increases, they are more likely to perceive the importance of elections (Denver 2003). Others have suggested that young voters are less informed about politics (Wattenberg 2002) and are therefore less likely to feel a sense of civic duty (Dalton 2008). Franklin (2004) has argued that low turnout among young people is not a necessary feature of being young, but rather is contingent on the electoral context in which new voters are socialized. Building on this argument and the "social logic of politics" (Zuckerman 2005), we seek to understand the pattern of electoral participation of young people by examining the social context of their first experience of voting.

\footnotetext{
${ }^{1}$ When an individual votes at an election, the electoral register is manually marked to indicate that an individual elector has voted. The data used in the analysis was collected with the support of the Joseph Rowntree Foundation and will be available for replication at http://www.humanities.manchester.ac.uk/socialchange/data by $1 / 4 / 2012$. An online appendix for this article is available at http:// journals.cambridge.org/jop containing supplemental analyses.
}

\section{Contextual Effects on Voting}

It is recognized that voters make decisions in context, and individual decisions about participation and party choice cannot be wholly explained by individual attributes (Agnew 1987; Cox 1969; Gimpel, Dyck, and Shaw 2004). The debate about the influence of geographical context on voting patterns has largely focused on neighborhood processes, emphasizing the effects of social networks and political discussion (Books and Prysby 1991). However, other important studies have shown that party-based mobilization (Fieldhouse and Cutts 2009; Pattie, Johnston, and Fieldhouse 1995; Rosenstone and Hansen 1993) and shared economic experiences (Pattie and Johnston 1995) are also important sources of "neighborhood effects." According to the theories of political interaction, when individuals make electoral choices, they take into account the values, expectations, and preferences of others, including: family, friends, work colleagues, and neighbors (Berelson, Lazarsfeld, and McPhee 1954; Huckfeldt and Sprague 1995; Lazarsfeld, Berelson, and Gaudet 1948). The role of social networks and interaction is encapsulated in the idea that "people who talk together, vote together" (Pattie and Johnston 2000), especially people in the same kinship networks (Huckfeldt and Sprague 1995). For example, the frequency of political discussion with a spouse has a positive effect on voter turnout (Zuckerman, Dasovic, and Fitzgerald 2007).

A number of studies have drawn attention to the household as the main locale where political discussions and decisions occur (Zuckerman 2005). Evidence suggests a powerful correlation between party choice and turnout of one member of a household and that of the others (Cutts and Fieldhouse 2009; Glaser 1960; Johnston et al. 2005; Straits 1990). A recent "get-out-the-vote" study found that $60 \%$ of the propensity to vote is passed on to other members of the household (Nickerson 2008). Other studies have found that some household relationships are more important than others. In particular, there is a strong link between the political proclivities of husbands and wives (Stoker and Jennings, 2005) and parents and children (Verba, Schlozman, and Burns 2005).

There is good reason to suppose that household effects may be important for young people, particularly insofar as the household is very often coterminous with the family. According to theories of political socialization that dominated political science between the 1950s and 1970s, political values and identities that underpin participation are acquired at an early age and remain fairly stable throughout the life course 
(Jennings and Niemi 1968; Jennings, Stoker, and Bowers 2009; Sapiro 2004). Socialization provides a lens through which social patterns that correspond to one's position in society are learned (Hyman 1959). Key socialization agents include most notably the family, but also schools and neighborhoods (Jennings and Niemi 1981). The importance of social group membership is reinforced by early socialization experiences that foster the development of partisan attachments or party identifications associated with social class memberships (Campbell et al. 1960). In turn, these influence the propensity to vote, as well as party choice.

\section{Voting as Habit}

The idea that voting is a habit is well established (Franklin 2004; Plutzer 2002; Verba and Nie 1972). Green and Shachar define habit as an act whose engagement in it "makes it more likely that one will engage in the same activity in the future" $(2000,562)$. This implies that going to the polls in one election will lead to a greater likelihood of returning to the polls in a subsequent election (Gerber, Green, and Shachar 2003), which will in turn lead to inertia (Cutts, Fieldhouse, and John 2009; Plutzer 2002). Habit is not only the repetition of the act itself, but also the specificity of the (stable) context in which it takes place. With regard to voting, this implies that repetition in voting behavior as well as context stability is important in understanding habitual voting (Aldrich et al. 2010).

Empirical evidence, though relatively sparse, is generally supportive of the notion (Cutts, Fieldhouse, and John 2009; Fowler 2006; Green and Shachar 2000; Gerber, Green, and Shachar 2003; Plutzer 2002), though behavioral models of turnout question whether habit exists at all (Bendor, Diermeier, and Ting 2003). There are a number of plausible mechanisms underpinning the habit of voting. One is that voting is self-reinforcing. The more often people vote, the more likely they regard this as normal behavior. The act of voting gives expression to an underlying preference for civic engagement, and these beliefs are periodically renewed each time an election takes place, reinforced by a process of selective perception. Studies of "foot-in-the-door" techniques seem to reinforce the idea that current participation makes future participation more likely (Freedman and Fraser 1966).

A different but complementary perspective is that voting on one occasion reduces the future cost of voting because voters accumulate knowledge (such as the location of the polling booth or the priorities of candidates), which they retain for use in subsequent elections (Plutzer 2002). There is still considerable room for doubt about the causal process driving the habit effect. In some cases the observed effect may result from capturing other processes that could not be construed as habit (such as attribute persistence). One approach to overcome this has been to deploy experimental designs. Two experimental studies from different electoral contexts demonstrate that after allowing for unobserved factors that might affect the propensity to vote, voting in one election increases the probability of voting in the next by as much as $50 \%$ (Cutts, Fieldhouse, and John 2009; Gerber, Green, and Shachar 2003). Another approach is to use panel data. Using the 1958 National Child Development Study, Denny and Doyle (2009) estimate the marginal effect of turning out at the previous election to be between $13 \%$ and $25 \%$. While more evidence is needed to establish the role of habit in voting, we do not aim to address that question here. Rather the theory and evidence discussed leads us to expect that first-time voters may respond to contextual stimuli differently from older electors.

\section{Bringing Together Context, Habit and First-Time Voting}

We have briefly described how voting is affected by context and habit. These processes are interrelated: which habits are acquired is dependent on context, and habit takes time to become established. Moreover, some agents of socialization are more influential than others, and exposure to these agents varies over the life course. Combining these ideas, we expect that household and neighborhood context may be especially important in shaping the electoral participation of young people. In other words, if the household is an important context for voters in general, it is likely to be especially important for first-time voters who are still learning their political and civic values and norms from their parents (Gimpel, Lay, and Schuknecht 2003; Niemi and Hepburn 1995). Equally, if young people are socialized in local networks where voting is standard, then they may take their cues from these neighborhood norms. We therefore might expect that young people living in households or in geographical locations that have higher rates of turnout will themselves be more likely to vote. However, household and spatial clustering of attitudes and behaviors are not necessarily attributable to contextual effects. There are a number of potential sources of household or neighborhood clustering derived from different theories of voting, including socioeconomic status, 
mobilization, and socialization. These arise because people who live in close proximity (or in the same household) tend to be more alike; they tend to be exposed to common experiences; and they are more likely to interact with each other. The most important of these mechanisms are likely to include shared socioeconomic and demographic characteristics; shared values and attitudes (through network effects or socialization effects); shared exposure to mobilization (e.g., by parties or neighbors); shared socioeconomic experience (e.g., local/household economic performance); common political contexts (e.g., candidate effects); and common genetic markers (at the family level).

At the level of the household, clustering may indicate that the decision to vote is a collective one and influenced by people having somebody to accompany them to the polling station (Cutts and Fieldhouse 2009). This is likely to be especially important for someone who is too young to have voted previously. Moreover, if voting is a habit, then while older people are set in their ways (as voters or abstainers), first-time electors are more open to influence from other people, either in their home or in their neighborhood. Previous research suggests young voters are relatively more likely to vote in a local election if they are personally contacted during a campaign (Green, Gerber, and Nickerson 2003) and more sensitive to the national electoral context (Fieldhouse, Tranmer, and Russell 2007). This is not to say that they are more informed about politics, which evidence suggests they are not (e.g., Wattenberg 2002), but rather that their participation is highly conditional.

By bringing together theories of context, habit, and socialization, we propose a number of hypotheses concerning the role of household and local context on the behavior of first-time electors. The hypotheses are:

H1: Turnout of first-time electors is lower than for those over 25;

H2: First-time electors' turnout is higher among those who live with other voters;

H3: The impact of living with other voters is stronger for first-time electors than for other electors;

H4: Turnout of first-time electors is influenced by neighborhood electoral context as measured by the local overall turnout rate; and

H5: Turnout of first-time electors is more sensitive to neighborhood context compared to turnout of other voters.

\section{Data}

Self-reporting of turnout is often unreliable due to over reporting of voting, and in the United Kingdom age is not recorded on the electoral register. However, we have one source of reliable data. "Attainers" are newly registered first-time electors (hereafter NRFTE) who come of age during the year of the election. Those who have reached the age of electoral majority in the past year are recorded on the official electoral register, making this a source of reliable information about first-time eligible voters.

Our main dataset consists of complete sets of marked electoral registers from a random stratified random sample of 57 electoral wards at the 2001 General Election. ${ }^{2}$ The sample contains wards from England and Wales and excludes postal voters, since for any given recipient of a postal vote, we do not know whether the vote was cast or not (Fieldhouse and Cutts 2007). The data file contains records for 1,239 NRFTE. A further 1,239 other voters were randomly selected from the same 57 wards as a comparator group. The sample of non-NRFTEs was stratified so it was structurally identical to the sample of NRFTEs in respect to representation by ward and household composition. The stratification ensures that the sample of NRFTEs and other electors are as similar as possible, both socioeconomically and demographically. The dataset used in the analysis therefore contained a sample of 2,478 electors nested in 57 wards. In addition, because this sample is derived from a larger database containing all electors in the sampled areas, we were able to derive summary information about other electors in each household and ward. We are therefore able to calculate the number of other voters and nonvoters in the household and ward of each member of the sample.

In addition to the sample of marked electoral registers, we use the British Household Panel Survey (BHPS $)^{3}$ to introduce factors not observed in the electoral registers. Here we use Wave 11 of the BHPS as it coincides with the 2001 General Election. The survey includes not only reported voting data for

\footnotetext{
${ }^{2} \mathrm{~A}$ ward is primarily an electoral division that forms the unit of representation in local government. Electoral wards typically have between 2,000 and 10,000 electors (average 5500).

${ }^{3}$ The BHPS is an annual panel survey consisting of a nationally representative sample of about 5,500 households recruited in 1991, containing a total of approximately 10,000 individuals. The survey is household-based, including every adult member of sampled households. BHPS data is available from the U.K. Data Archive http://www.esds.ac.uk/findingData/snDescription.asp?sn= 5151\&key=bhps under licence.
} 
households, but other important respondent characteristics. These data permit us to test whether any observed contextual effects are attributable to clustering in other characteristics, such as political interest or partisanship.

\section{Results}

Using the marked electoral registers described, we examined the rates of turnout of NRFTEs. In keeping with previous evidence and Hypothesis 1, we find that the overall turnout rate for NRFTEs $(50.0 \%)$ was lower than for other electors (54.9\%). Turning to the more specific question as to whether they are more sensitive to household context, Figure 1 shows the level of turnout for NRFTEs and non-NRFTEs according to the number of other voters in the household. The chart shows that for both groups, living with at least one other voter makes a huge difference to the propensity to vote. Having just one other voter in the household increases the chance of an NRFTE voting from $12.8 \%$ to $54.8 \%$ (or by a factor of 4.3). For other electors the equivalent factor is 2.8 , but starting from a higher level. The difference in ratios is larger if we compare the "household with no other voters" category with those containing two or three voters. In the latter categories, NRFTEs and other electors have an almost identical turnout rate of approximately $70 \%$. Overall, a young first-time elector living in a house where another adult goes out to vote is over five times more likely to vote than a counterpart in a household where nobody else votes (compared to less than three times for older electors). These substantial differences may go a long way in explaining the electoral participation rate of young people. This clearly supports Hypothesis 2, though

Figure 1 Percent Voting by Number of Other Voters in the Household

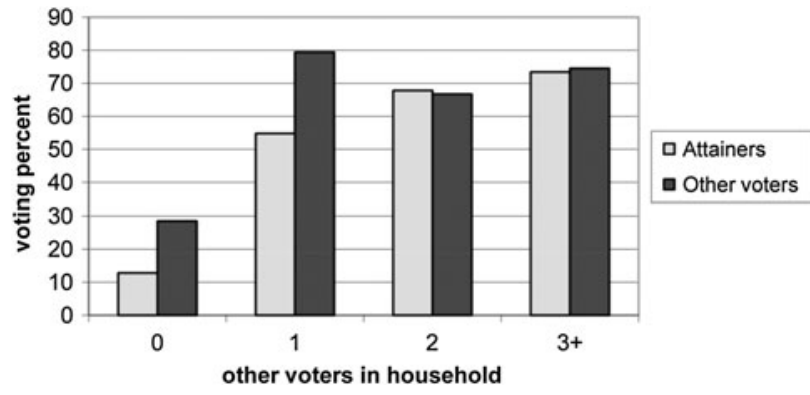

we still need to allow for other factors which may account for the differentials.

Turning to neighborhood context, following contextual theories of voting, there are two main ways in which the general level of electoral engagement may be connected with NRFTE turnout. First, if political talk is important, we might expect the presence of other voters in the immediate neighborhood to influence the behavior of individual NRFTEs. In this respect the local level of turnout represents a proxy for electorally engaged social networks outside of the household. Second, the local level of voting will reflect other influences on voting that vary from place to place. These might include the competitiveness of the local political contest, the strength of local party campaigns, or local economic conditions. Although we measure some of these things directly, the local level of turnout provides an excellent proxy for these factors. By using a local unit of geography which has political relevance-the electoral ward-we ensure that political factors such as marginality will be constant within our geographical units. Figure 2 shows the relationship between overall ward-level turnout and the turnout of NRFTEs. The correlation is fairly weak $\left(\mathrm{R}^{2}=0.27\right)$, but we see that as overall turnout increases, NRFTE turnout increases more rapidly. This is reflected in the steeper gradient of the best fit (thick) line compared to a 1:1 gradient or proportional line (dashed). Figure 2 also tells us that high overall ward turnout is a necessary but insufficient condition for NRFTEs' turnout. This is

\section{FIgure 2 Newly Registered Elector Turnout by Overall Ward Turnout}

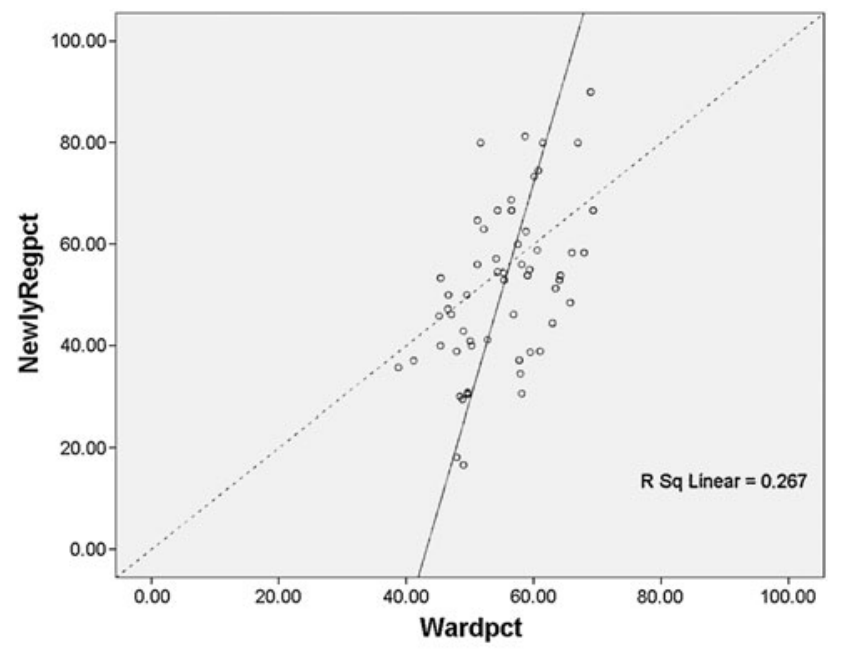

Note: The regression line shown represents the best fitting line of $\mathrm{x}$ on $\mathrm{y}$ (minimizing the squared deviations perpendicular to the line). 
consistent with the assertion that NRFTEs are more likely to be influenced by the local sociopolitical environment and suggests that their turnout may be dependent on the mobilizing influence of other electors.

Another way of testing the idea that first-time electors are especially sensitive to local context and prevailing electoral conditions is to examine the relationship between NRFTE turnout and specific indicators of political context. Fortunately we have some such indicators available, including the level of campaign spending and the marginality (or competitiveness) of the local constituency. The relationship between NRFTE turnout and spending is relatively weak $(+0.07)$. The relationship with marginality is shown in Table 1 . The turnout of both NRFTEs and other voters is only weakly related to the competitiveness of the parliamentary seat across most of the distribution, but NRFTE turnout drops quite sharply in very safe seats. Thus, there is evidence, albeit rather limited, to support the hypothesis that turnout for NRFTEs is influenced by local context (H4) and that this effect is greater for first-time voters than the rest of the electorate (H5).

\section{Multivariate Models}

The preceding section has provided some evidence in favor of each of our hypotheses. In particular, first-time electors are sensitive to household and local context and arguably more so than other voters. However, these relationships may be the result of household or neighborhood clustering of attributes correlated with turnout. For example, the propensity of voters to live with (or nearby) other voters may reflect the fact that people living together (or close to each other) are more likely to share demographic or socioeconomic attributes or political values. Although the data from the marked electoral registers contains only limited information at the individual level, we have developed a dual strategy to deal with this. Later we introduce survey data to try to control for the widest possible array of sources of

TABLE 1 Ward Context and Newly Registered FirstTime Electors Turnout (unweighted)

\begin{tabular}{lcc}
\hline Margin & NRFTE & Other \\
\hline $0-4.9 \%$ & $51.2 \%$ & $54.8 \%$ \\
$5-9.9 \%$ & $50.5 \%$ & $57.4 \%$ \\
$10-19.9 \%$ & $53.5 \%$ & $52.4 \%$ \\
$20-39.9 \%$ & $53.4 \%$ & $54.6 \%$ \\
$40 \%$ & $44.3 \%$ & $53.0 \%$ \\
\hline
\end{tabular}

household and neighborhood clustering. First, however, we attach small-area census data to individual electors in our sample of registered electors using simple geographical matching of postcodes (similar to zip codes). These are based on the smallest geographical units from the 2001 Census of Population, which are designed to be socially homogeneous and are therefore fairly good proxies for individual-level socioeconomic characteristics. ${ }^{4}$ Three factors-Working class, Affluence, and Retirement-were extracted using principal components analysis from nine census variables. ${ }^{5}$ We derived individual-level information about ethnic group ${ }^{6}$ and household size. This was used in multivariate models of voter turnout that compared the NRFTEs in the sample with an equivalent sized subsample of other electors. To test Hypotheses 1 through 3, the models also included NRFTE status, the presence of other voters in the household, and their interaction (to see if NRFTEs are more or less sensitive to household context than the control group). To test Hypotheses 4 and 5, we also added the political context (measured by the overall local turnout rate) and the interaction with NRFTE status.

The sample design suggests that a hierarchical modeling approach is necessary. Hierarchical modeling provides a framework for exploring how relationships vary across hierarchical structures, whether these are natural or introduced in the sample design. Because we are interested in measuring the effect of the presence of another voter in the household and how this varies by age, we specify the presence of another household voter as a fixed effect at the individual level, which is measured in interaction with age. As the sample is not clustered by household and contains only summary information about other electors at each address, household does not represent a level in the model. The modeling strategy is described in detail in the online appendix.

\section{Multivariate Results}

Table 2 shows the results of a series of two-level MCMC models of turnout. Model 1 represents a null

\footnotetext{
${ }^{4}$ The socioeconomic and demographic data is attached at the census Output Area, which consists of approximately 200 households.

${ }^{5}$ The nine census variables included in the factor analysis are: \% Long-term Ill, \% Unemployment, \% Owner Occupation, \% Manufacturing, \% Agriculture, \% Degree, \% Pensioners, \% Higher and Professional class, and \% Semiskilled and unskilled.

${ }^{6}$ This is derived using name recognition software. For an indepth discussion of the methodology, see Cutts, Fieldhouse, and John (2007).
} 
TAble 2 MCMC Estimates of a Two-Level Logistic Model of Turnout in 2001 General Election

\begin{tabular}{|c|c|c|c|c|c|c|c|}
\hline \multirow{2}{*}{$\frac{\text { Variables }}{\text { Intercept }}$} & $\begin{array}{c}\text { Model } 1 \\
\text { (null model) }\end{array}$ & \multicolumn{2}{|c|}{$\begin{array}{c}\text { Model 2 } \\
\text { NReg FTV \& Household } \\
\text { (fixed effects) }\end{array}$} & \multicolumn{2}{|c|}{$\begin{array}{c}\text { Model } 3 \\
\text { NReg FTV \& Ward } \\
\text { Turnout (fixed effects) }\end{array}$} & \multicolumn{2}{|c|}{$\begin{array}{c}\text { Model } 4 \\
\text { NReg FTV } \text { Fard }^{*} \text { arnout } \\
\text { Turnout }\end{array}$} \\
\hline & $0.10 \quad(0.06)$ & -0.92 & $(0.10)^{\star}$ & -1.77 & $(0.38)^{\star}$ & -1.59 & $(0.54)^{\star}$ \\
\hline NRFTE & - & -1.00 & $(0.19)^{\star}$ & -0.20 & $(0.08)$ & -0.43 & $(0.68)$ \\
\hline \multicolumn{8}{|l|}{ Household Effects } \\
\hline Household Other Voter & - & 2.07 & $(0.22)^{\star}$ & - & & & - \\
\hline NRFTE $x$ Household Other Voter & - & 0.48 & $(0.22)^{*}$ & - & & & - \\
\hline \multicolumn{8}{|l|}{ Level 2} \\
\hline$\%$ Ward Turnout & - & - & & 0.04 & $(0.01)^{\star}$ & 0.03 & $(0.01)^{\star}$ \\
\hline NRFTE $\mathrm{x} \%$ Ward Turnout & - & - & & - & & 0.00 & $(0.01)$ \\
\hline \multicolumn{8}{|l|}{ Random Part } \\
\hline Between-ward Variation & $0.086(0.040)^{\star}$ & 0.025 & $(0.025)$ & 0.034 & $(0.026)$ & 0.033 & $(0.025)$ \\
\hline DIC & 3409.24 & 283 & 9.05 & 339 & 3.23 & 3395 & 5.24 \\
\hline Sample Size & 2478 & & 78 & & 78 & 247 & 78 \\
\hline
\end{tabular}

Note: ${ }^{\star}$ Denotes significant at the 0.05 level. NRFTV $=$ Newly registered first-time electors; NREG FTV $=$ Newly registered first-time voters.

model that demonstrates significant between-ward variation in turnout. Using the latent variable approach (Goldstein and Rasbash 1996), the intraclass ward correlation is estimated to be $0.080 /$ $(0.080+3.29)$, which suggests that only $2.4 \%$ of the variation is at the ward level. Model 2 introduces the three key variables for testing Hypotheses 1-3. The statistically significant NRFTE "dummy" variable indicates that newly registered first-time electors not living with other voters are less likely to vote than their older counterparts (supporting H1). We see a strong positive coefficient for the presence of other voters in the household (supporting H2). Those living with others who voted are significantly more likely to vote than those who do not live with another voter. Most importantly, however, we see a significant positive interaction effect, reaffirming that NRFTEs are more sensitive to the presence of other voters in the household than the electorate more generally. That is, the presence of other voters offsets some of the baseline difference between NRFTEs and older voters. This is very likely because they have not yet acquired the habit of voting and are still developing their political behavior, making them more sensitive to the attitudes and behavior of others around them, especially their parents. The predicted turnout rate for a first-time elector living with another voter is $65 \%$, compared to $13 \%$ for those living with no other voters.

Models 3 and 4 look at the impact of local context. Unsurprisingly, while individual probabilities of turnout increase as ward-level turnout increases for all electors $(\mathrm{H} 4)$, we find no significant interaction between NRFTE status and ward turnout, leading us to reject Hypothesis 5. In other words, NRFTEs are not any more sensitive to the local context than other electors. This is also indicated by the goodness-of-fit statistics. The introduction of overall ward turnout led to a modest decrease in the DIC value from the null model, while the inclusion of the ward by NRFTE interaction did not improve the model fit. By contrast, the interaction of the NRFTE variable, the "household-other-voter," and interaction between the two, all led to a large and statistically significant reduction in the DIC value from Model 1 to Model 2 (Burnham and Anderson 2002). A dummy variable for very safe seats and its interaction with NRFTE status was also tested, but neither the main effect nor the interaction was significant.

Although the neighborhood contextual effects is not accentuated for first-time voters, it could be that that the (main) effect of neighborhood influences is being transmitted by more experienced voters in the household to the young voters. This would help explain why young voters who are less informed about elections might be more sensitive to electoral context (e.g., Fieldhouse, Tranmer, and Russell 2007). In order to test whether the effect of ward context is mediated by the presence of mobilizing agents in the household, we fitted the equivalent of model 4 on the sample of NRFTE only. This allows us to test whether, for NRFTE, the significant neighborhood effect found in Model 4 is conditional on the presence of these mobilizing agents. We again found strong effects for the presence of other voters in the household, but 
found no significant interaction with ward context (see online appendix Table A1). In other words, household effects are operating independently from neighborhood effects and are not transmitting those effects.

In Table 3 (model 4) we introduce the sociodemographic, household, and local covariates as described above in order to test whether the observed results are simply a reflection of other factors. We find that the additional covariates introduced are all significant and in the direction anticipated: people in larger households (defined as those containing more than three electors) are less likely to vote (Johnston et al. 2005), while South Asian electors are more likely to vote (Fieldhouse and Cutts 2008). People from workingclass backgrounds are less likely to vote than their middle-class counterparts, and those from richer neighborhoods and from retirement communities are more likely to vote. Having controlled for these socioeconomic and household effects, there is no longer any significant relationship between voting and ward context. This suggests we can reject both Hypothesis 4 and Hypothesis 5. That is, after controlling for household and neighborhood composition, there are no significant neighborhood effects on turnout for first-time voters.

\section{TABle 3 MCMC Estimates of a Two-Level Logistic Model of Turnout in 2001 General Election}

\begin{tabular}{lcc}
\hline Variables & \multicolumn{2}{c}{ Model 4 } \\
\hline Intercept & -1.88 & $(0.67)^{\star}$ \\
NRFTE & -0.97 & $(0.19)^{\star}$
\end{tabular}

\section{Household Effects}

Household Other Voter

NRFTE x Household Other Voter

$2.08(0.14)^{\star}$

$0.54(0.22)^{\star}$

Level 1 Controls

Multiple Household

Asian

$-0.58(0.11)^{*}$

$0.49(0.13)^{\star}$

Socioeconomic Composition (OA)

Factor 1: Working Class

Factor 2: Affluence

$-0.17(0.05)^{\star}$

$0.16(0.06)^{*}$

Factor 3: Retirement

$0.11(0.05)^{\star}$

Level 2 Fixed Effects

Margin

\% Ward Turnout

$0.01 \quad(0.00)$

$0.01 \quad(0.01)$

\section{Random Part}

Between-ward Variation

DIC

$0.016(0.019)$

2790.52

Sample Size

Note: ${ }^{\star}$ Denotes significant at the 0.05 level. NRFTE $=$ Newly registered first-time electors.

When we look to the household context, however, the picture is rather different. Overall first-time electors are less likely to turn out than their older counterparts, as previously indicated. Furthermore, people living in households with other voters are significantly more likely to vote than those who do not. What is crucial, however, is the significant positive interaction term: having controlled for various other factors, first-time electors are even more sensitive to the presence (or lack) of other voters in the household, providing further strong support for Hypothesis 3. Estimating the predicted probabilities from this model, we find that a first-time elector in the reference category and in an average turnout area who lives with another voter has an $83 \%$ chance of voting compared to only $27 \%$ for one who does not. In other words, the household effect is not a reflection of more "well-todo" electors being more likely to live in households where other voters live, but is independent of socioeconomic characteristics or household size.

A final and stricter test is whether these findings persist after taking into account political interest, partisanship, and a range of other correlates of turnout that may be clustered within households. In other words, could these findings simply reflect the possibility that - for a variety of reasons relating to the intergenerational transmission of political attitudes and orientations through socialization (Gimpel, Lay, and Schuknecht 2003) — people with similar levels of attachment to political parties and levels of interest in politics ${ }^{7}$ are more likely to live together? This is a much stricter test of our Hypothesis 5, which allows us to isolate that part of the effect that is attributable to shared values and characteristics. We suggest that the residual NRFTE/ household-voter interaction effect may be due to the impact of the availability of a companion to accompany the young person to the polling booth. In other words people living together don't just think alike, they vote together. To explore this, we turn to data from the British Household Panel Study (2001), which is contemporaneous with our other data and includes relevant attitudinal information. ${ }^{8}$

The BHPS includes 169 respondents who were aged 18 years old at the time of the election and are

\footnotetext{
${ }^{7}$ We also included attitudinal questions regarding efficacyincluding "Ordinary people can't influence government" and whether individuals felt that "Government reflects the will of the people" — and relevant household characteristics including education of head of household (see Table 4).

${ }^{8}$ The BHPS does not contain the voting companion question. We have circumstantial evidence for this explanation provided by the unexplained household effects and the supplementary evidence from the Canadian and Italian election studies.
} 
therefore equivalent to the group of NRFTEs derived from the marked electoral register. ${ }^{9}$ These were all included in our subsample together with all voters aged 19-22. As previously, we match this sample of young voters with a random sample of other voters, proportionate in terms of household composition, and from the same geographical locations. ${ }^{10}$ Age is divided into a series of categories because of the nonlinear relationship with vote. In order to observe whether the impact of living with other voters tails off quickly as young people establish the habit of voting (or abstention), we retain more detailed categories for the younger respondents (made possible by the oversampling of young respondents). The reference category is those aged 26-30, adults relatively close in age to the NRFTEs, but who have had sufficient time to establish a habit of voting. The presence of another voter in the household is measured at the individual level and interacted with age to show how the strength of the effect varies over the life course. Whether the household is made up of a single elector, a family group, or a nonfamily group is also included. We do not know the neighborhood location in the BHPS, though given that we have already rejected Hypothesis 4 and Hypothesis 5, this does not present a serious problem. Table 4 shows the results of a logistic regression analysis of turnout.

The first model shows the impact of age, the presence of other voters in the household, and the interaction effects. The model confirms what our analysis of the electoral registers told us - that firsttime electors were especially sensitive to the presence of other voters in the household as demonstrated by the significant positive interaction effect. This effect drops immediately as the electors reach the age of 19 (but remains statistically significant) and then falls to insignificance at the age of 21 . A significant interaction reemerges at the age of 31 , presumably reflecting the establishment of longer-term stable family relationships that are also politically influential. At all

\footnotetext{
${ }^{9}$ In the following analyses (shown in Table 4) we classify NRFTE (using to date of birth of the respondent) as all respondents who reached aged 18 between October 2000 and the date of the 2001 election (June 7th 2001). This is directly equivalent to NRFTEs on the electoral register as the 2001 electoral registers were compiled in October 2000. Age 19\&20 are defined as those respondents who were aged 19 on election day and were already aged 18 or more in October 2000, plus all 20 year olds.

${ }^{10}$ There is a small degree of clustering in the sample, as some young respondents in the oversample were located at the same address as each other or at the same address as older electors in the subsample. Overall, 19\% of households contained more than one respondent, and therefore robust standard errors adjusted for household clustering are used in calculating significance in Table 4.
}

ages, the interaction effect remains positive (compared to the reference category 26-30), but smaller than that at age 18 .

The different trajectories of voting probability for those living with other voters (and those not) is illustrated in Figure 3, which shows the predicted probability of voting by age from model 1 . As expected, the dashed line (representing electors living with no other participating voters) is lower than the solid line (representing those who live with other voters). Both lines slope upwards with age, as the probability of voting increases as one gets older (as seen from the main effects in model 1). The gap between the two lines narrows abruptly after age 18 and continues to narrow more slowly with age. This indicates that the relative effect of living with another voter diminishes over the early part of the life course and that the impact of living with other voters is stronger for first-time electors than for those who have enjoyed previous opportunities to vote.

This does not provide a direct test of the effect of habit. Rather, there are two plausible interpretations of this pattern. First, consistent with the "habit" interpretation, it may be that as the effect of habit kicks in, the influence of other voters diminishes. By definition the NRFTE category has had no previous opportunity to vote. Each subsequent older category has had (increasing) numbers of opportunities to vote at local elections. Thus the decline in the companion effect may reflect a hardening of voting habits over time. The second interpretation is that these represent life-cycle variations in the size of the household contextual effect that reflect changes in family structure and household relationships. According to this interpretation, the drop in the size of the interaction after the age of 18 and the subsequent increase after the age of 31 reflects the tendency of young people to move away from their parents and live with people with whom they share weaker ties. As they reach their 30s and form families of their own, the importance of household influence starts to increase again. This is tested further below, but whether one or both of these interpretations is correct, the enhanced life-cycle effect for new electors is consistent with our hypothesis (H3) and with the analysis of electoral registers above.

In model 2, we add a number of control variables that are significantly related to turnout, and, by virtue of being clustered within households, may account for the impact of living with other voters. These include political interest, strength of partisan identification, various indicators of efficacy and trust, marital status, education of household head, and household size. We also control for whether or not other electors in the 
TABLE 4 Logit Model of Turnout in 2001 General Election (BHPS data)

\begin{tabular}{|c|c|c|c|}
\hline Variables & Model 1 & Model 2 & Model 3 \\
\hline Constant & $-0.68^{\star}$ & $-1.72^{*}$ & $-1.45^{\star}$ \\
\hline $\begin{array}{l}\text { Household Effects } \\
\text { Household Other Voter }\end{array}$ & $1.19^{*}$ & $1.47^{\star}$ & $1.04^{\star}$ \\
\hline $\begin{array}{l}\text { Household Type: Base }=\text { Nonfamily Adult } \\
\text { Single Adult } \\
\text { Family Group } \\
\text { Family Group x Household Other Voter }\end{array}$ & $\begin{array}{l}- \\
- \\
-\end{array}$ & $\begin{array}{c}0.75^{\star} \\
-0.01 \\
-\end{array}$ & $\begin{array}{c}0.29 \\
-0.59^{\star} \\
0.99^{\star}\end{array}$ \\
\hline $\begin{array}{l}\text { Other Age Groups: Base }=\text { Age } \mathbf{2 6 - 3 0} \\
\text { NRFTE } \\
\text { Age } 19 \text { in Oct \& } 20 \\
\text { Age } 21 \& 22 \\
\text { Age } 23-25 \\
\text { Age } 31-40 \\
\text { Age } 41-50 \\
\text { Age } 51-60 \\
\text { Age } 60 \text { Plus }\end{array}$ & $\begin{array}{c}-1.19^{\star} \\
-0.53^{\star} \\
-0.25 \\
-0.24 \\
0.45^{\star} \\
0.96^{\star} \\
1.21^{\star} \\
1.88^{\star}\end{array}$ & $\begin{array}{l}-0.79 \\
-0.57^{\star} \\
-0.25 \\
-0.31 \\
0.48^{\star} \\
0.93^{\star} \\
1.12^{\star} \\
1.48^{\star}\end{array}$ & $\begin{array}{c}-0.10 \\
-0.31 \\
-0.18 \\
0.03 \\
0.68^{\star} \\
1.19^{\star} \\
1.28^{\star} \\
1.75^{\star}\end{array}$ \\
\hline $\begin{array}{l}\text { Interaction Effects } \\
\text { NRFTE x Household Other Voter } \\
\text { Age } 19 \& 20 \times \text { Household Other Voter } \\
\text { Age } 21 \& 22 \times \text { Household Other Voter } \\
\text { Age } 23-25 \times \text { Household Other Voter } \\
\text { Age } 31-40 \times \text { Household Other Voter } \\
\text { Age } 41-50 \times \text { Household Other Voter } \\
\text { Age } 51-60 \times \text { Household Other Voter } \\
\text { Age } 60 \text { plus x Household Other Voter }\end{array}$ & $\begin{array}{l}1.16^{\star} \\
0.39 \\
0.24 \\
0.55 \\
0.59^{\star} \\
0.63^{\star} \\
0.52 \\
0.62^{\star}\end{array}$ & $\begin{array}{l}1.00^{*} \\
0.44 \\
0.17 \\
0.68 \\
0.41 \\
0.54 \\
0.35 \\
0.74^{\star}\end{array}$ & $\begin{array}{l}- \\
- \\
- \\
- \\
- \\
- \\
- \\
-\end{array}$ \\
\hline $\begin{array}{l}\text { Political Engagement } \\
\text { Political Support } \\
\text { Political Interest }\end{array}$ & $\begin{array}{l}- \\
-\end{array}$ & $\begin{array}{l}1.18^{*} \\
0.95^{*}\end{array}$ & $\begin{array}{l}1.19^{*} \\
0.96^{*}\end{array}$ \\
\hline $\begin{array}{l}\text { Govt. Reflects Will of People: Base }=S D \text { \& Disagree } \\
\text { Strongly Agree } \\
\text { Agree } \\
\text { Neither Agree nor Disagree }\end{array}$ & $\begin{array}{l}- \\
- \\
-\end{array}$ & $\begin{array}{l}0.62 \\
0.25^{\star} \\
0.02\end{array}$ & $\begin{array}{l}0.62 \\
0.25^{\star} \\
0.03\end{array}$ \\
\hline $\begin{array}{l}\text { Govt. Puts Nation before Party: Base }=S D \text { \& Disagree } \\
\text { Strongly Agree } \\
\text { Agree } \\
\text { Neither Agree nor Disagree }\end{array}$ & $\begin{array}{l}- \\
- \\
-\end{array}$ & $\begin{array}{r}-0.38 \\
-0.09 \\
0.04\end{array}$ & $\begin{array}{r}-0.39 \\
-0.09 \\
0.04\end{array}$ \\
\hline $\begin{array}{l}\text { Head of Household Education: Base = Below Post } 16 \\
\text { Degree } \\
\text { Post } 16 \text { Qualifications below Degree } \\
\text { Missing }\end{array}$ & $\begin{array}{l}- \\
- \\
-\end{array}$ & $\begin{array}{l}0.08 \\
0.38^{*} \\
0.78^{*}\end{array}$ & $\begin{array}{l}0.09 \\
0.41^{\star} \\
0.80^{\star}\end{array}$ \\
\hline $\begin{array}{l}\text { Model Fit } \\
\text { Log Likelihood } \\
\text { LR Chi-square } \\
\text { Pseudo R }{ }^{2} \\
\text { N }\end{array}$ & $\begin{array}{l}-2700.31 \\
849.59 \\
0.19 \\
5232\end{array}$ & $\begin{array}{c}-2403.04 \\
1107.17 \\
0.28 \\
5232\end{array}$ & $\begin{array}{c}-2398.07 \\
1109.03 \\
0.28 \\
5232\end{array}$ \\
\hline
\end{tabular}

Note: ${ }^{\star}$ Denotes significant at the 0.05 level. See footnote 9 above. The reference categories are: no voters in household, non-family adult, age 26-30, Govt reflects will of people (disagree), Govt puts nation before party (disagree), no post 16 education. 
FIgURE 3 Predicted Probability of Voting (BHPS, model 1)

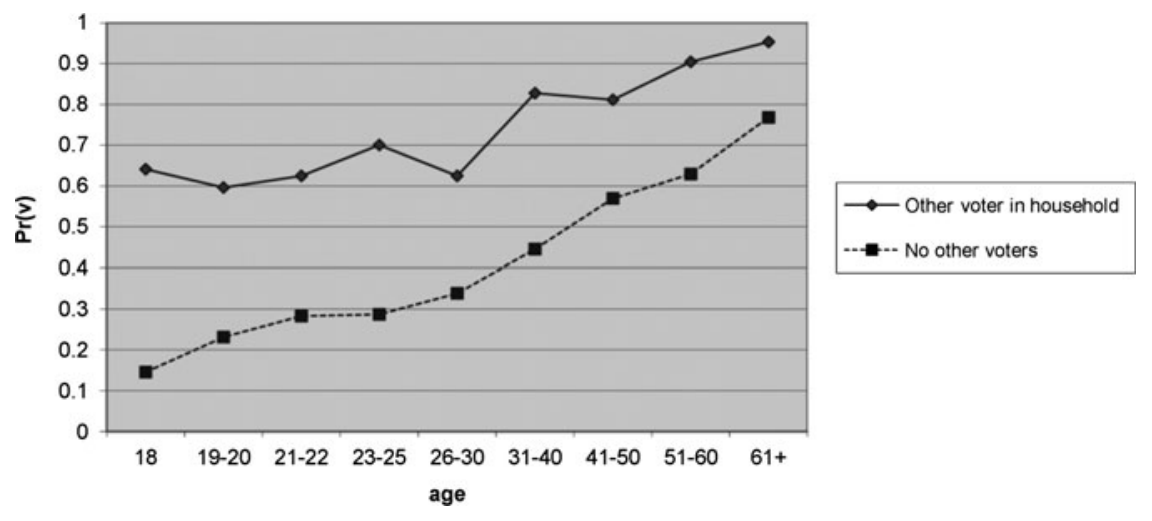

household are from the same family as the respondent. Should the inclusion of these variables remove the "household-other-voter" and interaction effect, then we could surmise that the connection between the voting behavior of young people and living with another voter is attributable to the tendency for household members to share particular political or demographic characteristics. However, we see in model 2 that this is not the case. The impact of the "householdother-voter" variable is still significant and positive. ${ }^{11}$ Moreover, its interaction with NRFTE status is also significant and in the direction hypothesized. With the exception of the oldest age group, after age 18 none of the interactions are significant, and the gap in Figure 2 remains fairly constant. In other words, living with another voter has a strong impact on the tendency to vote, and this is especially true of first-time electors, confirming Hypotheses 2 and 3.

In order to test whether household contextual effects are more pronounced where household members belong to the same family, we add an interaction between household-other-voter and a family-group indicator (model 3). ${ }^{12}$ As noted above, it is possible that the pattern of effects shown in Figure 3 reflects life-cycle differences in household relationships. The enhanced effects for first-time voters may come about because they are more likely to live with immediate family members (which may also be true for those over 30 for whom we also find significant interaction effects). This is partly born out in model 3, which shows that household contextual effects are indeed

\footnotetext{
${ }^{11}$ The coefficient for single elector is positive, but this is always offset by the lack of other household voters.

${ }^{12} \mathrm{We}$ remove the age interaction here to aid interpretability. In order to test the possible three-way interaction, we modeled firsttime voters, other voters under 30 and voters over 30 separately.
}

stronger for family groups than nonfamily groups (as measured by the interaction term). Parents may simply be more effective at persuading their offspring to vote than spouses or roommates.

To test whether the enhanced contextual effect for new voters (NRFTEs) reflects this family effect, we stratified model 3 by age (see online Appendix 2, Table A2). The models showed that the positive effect of household context was only present for new voters if they lived in a family group (i.e., the main effect for living with another voter was not significant, but the interaction with living with family was significant and positive). Older voters were more likely to vote if they lived with other voters, regardless of whether they lived with family. However, other voters under 30 also saw an additional boost to turnout if household members belonged to the same family (the main effects and interaction were significant).

Thus we find that while controlling for a wide range of social and attitudinal variables including partisanship does not completely rule out unobserved causes of household clustering in voting, it does strongly suggest that contextual exposure to other voters has an important role. This is largely due to stronger household effects where household members belong to the same family.

\section{Conclusions}

Existing theories and empirical evidence concerning political participation and voting have taught us the importance of three interconnected phenomena. First, as the many studies of political socialization have shown over the years, participation is in part learned at an early age, through the family, through schools, and through local neighborhood experiences 
(Hyman 1959; Jennings and Niemi 1981). Second, the voting decision is made not in isolation, but by individuals in the social context of the household (Zuckerman 2005) and in the neighborhood (Cox 1969). Third, the act of voting is habit forming. Once an elector has voted once, he or she is more likely to vote on a subsequent occasion (Green and Shachar 2000). In this article, we have demonstrated how by integrating these theories of voting we are able to provide a powerful account of first-time voting. We have found evidence to accept the hypotheses that first-time electors are less likely to vote (H1); that all electors are considerably more likely to vote if they live with other voters $(\mathrm{H} 2)$; and that the effect of living with other voters is stronger for first-time electors than for other electors (H3). By contrast we find little evidence that turnout of first-time electors is influenced by neighborhood electoral context any more than anyone else (H4, H5).

This null finding concerning neighborhood context leaves open the puzzle that emerges from previous research. Why are young voters, who are less informed about elections and less likely to be knowledgeable about the political context, more influenced by contextual effects (e.g., Fieldhouse, Tranmer, and Russell 2007)? Despite the null finding, our results relating to household context offer an answer to this: young people are more easily influenced by other mobilizing agents, which in turn may explain why they are often more sensitive to contextual effects. We argue that because young people have not yet formed the habit of voting or abstention, they are potentially more easily mobilized (or demobilized). Moreover, at the age of 18 many first-time voters live with arguably the most important socialization agents - their parents-and we show that the decision of young first-time electors to vote is highly dependent on the participation of others in their family. This effect can be either positive or negative insofar as the absence of mobilizing agents for young people produces lower turnout, just as their presence enhances turnout for the same group. Young firsttime electors living with other voters were found to be as much as three to four times more likely to vote than similar young electors living with nonvoters, and these differences survived controls for a variety of sociodemographic and even attitudinal factors, including political interest.

Nevertheless, there are limitations to the analysis and room for further research. Ideally we would have information within a single dataset about each and every voter in every household in a large number of neighborhoods, including with whom they went to vote and their social political and economic characteristics. Unfortunately, at present, such data do not exist, so we must piece together the evidence and use a certain amount of conjecture to draw these conclusions. It is not possible from the analyses conducted above to ascertain whether the sensitivity of young people to household contextual effects is attributable to differential sensitivity to context (and lack of habit) or to life-cycle variations in the identity of socializing agents. However, we did ascertain that household contextual effects were greater for family groups, especially for first-time voters.

Given that this effect does not appear to be directly attributable to household composition or a wide range of political attitudes and socioeconomic characteristics, we suggest that it is likely to be at least partly a reflection of the social aspects of voting, what we have referred to as the "companion effect." This assertion is supported indirectly by independent survey evidence from Canada and from Italy. In Italy in 1996 approximately two-thirds of voters attended the polling with somebody else, with parents being the most common category for voters aged 20 or under. In 2011 in Canada and Italy, over half of voters who voted in person were accompanied to the polling station. ${ }^{13}$ The vast majority of these (over $90 \%$ in both countries) were family members living at the same address. As Glaser noted 40 years ago, "turnout tends to be a joint household activity" (1960, 569). Whether or not our findings can be accounted for by the companion effect, the scale of the household effect suggests that studies of youth voting must in future pay greater attention to household processes and to understanding the social logic of youth turnout.

\section{Acknowledgments}

We gratefully acknowledge the contribution of Professor Andrew Russell for comments and suggestions on early versions of this article.

\section{References}

Agnew, John. 1987. Place and Politics: The Geographical Mediation of State and Society. Boston: Allen and Unwin.

Aldrich, J. H., J. M. Montgomery, et al. (2010) "Turnout as a Habit.” Political Behavior Online First. DOI: 10.1007/s11109010-9148-3.

\footnotetext{
${ }^{13}$ Source: Italian Election Study, 1996; Canadian Election Study 2011, ITANES 2011.
} 
Bendor, J., D. Diermeier, and M. Ting. 2003. "A Behavioral Model of Turnout." American Political Science Review 97 (2): 261-80.

Berelson, Bernard R., Paul F. Lazarsfeld, and William N. McPhee. 1954. Voting. Chicago: Chicago University Press.

Blais, André. 2006. "What Affects Voter Turnout?" Annual Review of Political Science, 9: 111-25.

Blais, André. 2000. To Vote or Not to Vote? The Merits and Limits of Rational Choice Theory. Pittsburgh, PA: University of Pittsburgh Press.

Books, John, and Charles Prysby. 1991. Political Behavior and the Local Context. New York: Praeger.

Butler, David, and Donald Stokes. 1974. Political Change in Britain. $2^{\text {nd }}$ ed. Basingstoke, UK: Palgrave Macmillan.

Burnham, Kenneth, and David Anderson. 2002. Model Selection and Multi-Model Inference: A Practical-Theoretical Approach. $2^{\text {nd }}$ ed. New York: Springer.

Campbell, A., P. E. Converse, W. E. Miller, and D. Stokes. 1960. The American Voter. Chicago: Chicago University Press.

Cox, Kenneth R. 1969. "The Voting Decision in a Spatial Context." Progress in Geography 1: 81-117.

Cutts, David, Edward Fieldhouse, and Peter John. 2009. "Is Voting Habit Forming? The Longitudinal Impact of a GOTV Campaign in the UK." Journal of Elections, Public Opinion and Parties 19 (3): 251-63.

Cutts, David, and Edward Fieldhouse. 2009. "What Small Spatial Scales are Relevant as Electoral Contexts for Individual Voters? The Importance of the Household on Turnout at the 2001 General Election." American Journal of Political Science 53 (3): 726-39.

Dalton, Russell J. 2008. The Good Citizen: How a Younger Generation is Reshaping American Politics. Washington, D.C.: CQ Press.

Denny, K. and O. Doyle (2009). "Does Voting History Matter? Analysing Persistence in Turnout." American Journal of Political Science 53 17-35.

Denver, David. 2003. Elections and Voters in Britain. Basingstoke, UK: Palgrave MacMillan.

Fieldhouse, Edward, and David Cutts. 2009. "The Effectiveness of Local Party Campaigns in 2005: Combining Evidence from Campaign Spending, Agent Survey Data and Individual Level Data." British Journal of Political Science 39 (1): 367-88.

Fieldhouse, Edward, and David Cutts. 2008. "Diversity, Density and Turnout: The Effect of Neighborhood Ethno-Religious Composition on Voter Turnout in Britain." Political Geography 27 (5): 530-48.

Fieldhouse, Edward, and David Cutts. 2007. Electoral Participation in Britain's South Asian Communities. York, UK: Joseph Rowntree Foundation.

Fieldhouse, Edward, Mark Tranmer, and Andrew Russell. 2007. "Something about Young People or Something about Elections? Electoral Participation of Young People in Europe: Evidence from a Multilevel Analysis of the European Social Survey." European Journal of Political Research 46 (6): $797-$ 822.

Fowler, James. H. 2006. "Habitual Voting and Behavioral Turnout." The Journal of Politics 68 (2): 335-44.

Franklin, Mark. 2004. Voter Turnout and the Dynamics of Electoral Competition in Established Democracies. Cambridge: Cambridge University Press.

Franklin, Mark. 1996. "Electoral participation." In Comparing Democracies: Elections and Voting in Global Perspective, ed.
Larry LeDuc, Richard Niemi and Pippa Norris. Newbury Park, CA: Sage, 220-22.

Freedman, J. L., and S. C. Fraser. 1966. "Compliance without Pressure: The Foot-in-the-Door Technique." Journal of Personality and Social Psychology 4 (2): 196-202.

Gerber Alan, Donald Green, and Ron Shachar. 2003. "Voting May Be Habit-Forming: Evidence from a Randomized Field Experiment." American Journal of Political Science 47 (3): 540-50.

Gimpel, James, Joshua Dyck, and Daron Shaw. 2004. "Registrants, Voters and Turnout Variability across Neighborhoods." Political Behavior 26 (4): 292-310.

Gimpel, James, C. J. Lay, and J. E. Schuknecht. 2003. Cultivating Democracy. Civic Environments and Political Socialization in America. Washington, DC: Brookings Institution Press.

Glaser, William, A. 1960. "The Family and Voting Turnout." Public Opinion Quarterly 23 (4): 563-70.

Goldstein, Harvey, and Jon Rasbash. 1996. "Improved Approximations for Multilevel Models with Binary Responses," Journal of Statistical Society A 159 (3): 505-13.

Green, Donald, Alan Gerber, and David Nickerson. 2003. "Getting Out the Vote in Local Elections: Results from Six Door-to-Door Canvassing Experiments." Journal of Politics 65 (4): 1083-96.

Green, Donald, and Ron Shachar. 2000. "Habit Formation and Political Behavior: Evidence of Consuetude in Voter Turnout." British Journal of Political Science 30 (4): 561-73.

Huckfeldt, Robert, and John Sprague. 1995. Citizens, Politics and Social Communication: Information and Influence in an Election Campaign. Cambridge: Cambridge University Press.

Hyman, Herbert Hiram. 1959. Political Socialization: A Study in the Psychology of Political Behavior. Glencoe, IL: Free Press.

Jennings, Kent. M., and Richard Niemi. 1968. "The Transmission of Political Values from Parent to Child." American Political Science Review 62 (1): 169-84.

Jennings, Kent, M., and Richard Niemi. 1981. Generations and Politics. Princeton, NJ: Princeton University Press.

Jennings, Kent, M., Laura Stoker, and Jake Bowers. 2009. "Politics across Generations: Family Transmission Reexamined." Journal of Politics 71: 782-99.

Johnston, Ronald J., Kelvyn Jones, Carol Propper, Rebecca Sarker, Simon Burgess, and Anne Bolster. 2005. "A Missing Level in the Analyses of British Voting Behavior: The Household as Context as Shown by Analyses of a 1992-1997 Longitudinal Survey." Electoral Studies 24 (2): 201-25.

Lazarsfeld, Paul. F., Bernard Berelson, and Hazel Gaudet. 1948. The People's Choice. New York: Columbia University Press.

Nickerson, David. 2008. "Is Voting Contagious? Evidence from Two Field Experiments." American Political Science Review 102 (1): 49-57.

Niemi, R. G., and M. A. Hepburn. 1995. "The Rebirth of Political Socialization." Perspectives on Political Science 24 (1): 7-16.

Pattie, Charles J., and Ronald J. Johnston. 2000. "People who Talk Together Vote Together: An Exploration of Contextual Effects in Great Britain." Annals of the Association of American Geographers 90 (1): 41-66.

Pattie, Charles J., and Ronald J. Johnston. 1995. "It's not Like that Round Here: Region, Economic Evaluations and Voting at the 1992 British General Election." European Journal of Political Research 28 (1): 1-32.

Pattie, Charles J., Ronald. J. Johnston, and Edward Fieldhouse. 1995. "Winning the Local Vote: The Effectiveness of 
Constituency Campaign Spending in Great Britain 19831992." American Political Science Review 89 (4): 969-86.

Plutzer, Eric. 2002. "Becoming a Habitual Voter: Inertia, Resources and Growth in Young Adulthood." American Political Science Review 96 (1): 41-56.

Rosenstone, S. and J. Hansen. 1993. Mobilization, Participation and Democracy in America. New York: Macmillan.

Sapiro, Virginia. 2004. "Not Your Parents Political Socialization: Introduction for a New Generation." Annual Review of Political Science 7: 1-23.

Straits, Bruce C. 1990. "The Social Context of Voter Turnout." Public Opinion Quarterly 54 (1): 64-73.

Stoker, L., and K. Jennings. 2005. "Political Similarity between Husbands and Wives." In The Social Logic of Politics, ed. Alan Zuckerman. Philadelphia: Temple University Press, 51-74.

Topf, R. 1995. "Electoral Participation.” In Citizens and the State, ed. H.-D. Klingemann and D. Fuchs. Oxford: Oxford University Press: 52-91.

Verba, S. and H. Nie. 1972. Participation in America: Political Democracy and Social Equality. New York: Harper and Row.

Verba, S., K. Schlozman, and N. Burns. 2005. "Family Ties: Understanding the Intergenerational Transmission of Political Participation." In The Social Logic of Politics, ed.
Alan Zuckerman. Philadelphia: Temple University Press, 95-114.

Wattenberg, Marty. 2002. Where Have All the Voters Gone? Cambridge, MA: Harvard University Press.

Zuckerman, Alan. 2005. The Social Logic of Politics. Philadelphia: Temple University Press.

Zuckerman, Alan, Josip Dasovic, and Jennifer Fitzgerald. 2007. Partisan Families: The Social Logic of Bounded Partisanship in Germany and Britain. New York: Cambridge University Press.

Edward Fieldhouse is Professor of Social and Political Science and Director of the Institute for Social Change, School of Social Sciences, Humanities Bridgford Street at the University of Manchester, M13 9PL, UK.

David Cutts is a Research Fellow at the Institute for Social Change, School of Social Sciences, Humanities Bridgford Street at the University of Manchester, M13 9PL, UK. 